Review

\title{
Fruit Pod Extracts as a Source of Nutraceuticals and Pharmaceuticals
}

Azila Abdul Karim ${ }^{1}$ and Azrina Azlan ${ }^{2,3, *}$

1 Cocoa Innovation \& Technology Centre, Malaysian Cocoa Board, PT12621, Nilai Industrial Area, 71800 Nilai, Negeri Sembilan, Malaysia; E-Mail: aziela@koko.gov.my

2 Department of Nutrition and Dietetics, Faculty of Medicine and Health Sciences, Universiti Putra Malaysia, 43400 UPM Serdang, Selangor, Malaysia

3 Laboratory of Halal Science Research, Halal Products Research Institute, Universiti Putra Malaysia, 43400 UPM Serdang, Selangor, Malaysia

* Author to whom correspondence should be addressed; E-Mail: azrina@medic.upm.edu.my; Tel.: +603-8947-2466; Fax: +603-8942-6769.

Received: 21 June 2012; in revised form: 27 September 2012 / Accepted: 29 September 2012 / Published: 10 October 2012

Abstract: Fruit pods contain various beneficial compounds that have biological activities and can be used as a source of pharmaceutical and nutraceutical products. Although pods or pericarps are usually discarded when consuming the edible parts of fruits, they contain some compounds that exhibit biological activities after extraction. Most fruit pods included in this review contain polyphenolic components that can promote antioxidant effects on human health. Additionally, anti-inflammatory, antibacterial, antifungal and chemopreventive effects are associated with these fruit pod extracts. Besides polyphenolics, other compounds such as xanthones, carotenoids and saponins also exhibit health effects and can be potential sources of nutraceutical and pharmaceutical components. In this review, information on fruit pods or pericarp of Garcinia mangostana, Ceratonia siliqua, Moringa oleifera, Acacia nilotica, Sapindus rarak and Prosopis cineraria is presented and discussed with regard to their biological activity of the major compounds existing in them. The fruit pods of other ethno- botanical plants have also been reviewed. It can be concluded that although fruit pods are considered as being of no practical use and are often being thrown away, they nevertheless contain compounds that might be useful sources of nutraceutical and other pharmaceutical components. 
Keywords: fruit pods; bioactive; nutraceutical; pharmaceutical

\section{Introduction}

A nutraceutical is defined as any substance that is food or a part of food that provides medical or health benefits, for the prevention and treatment of diseases [1]. Nutraceuticals include a broad range of categories such as dietary supplements, functional foods and herbal products [2]. The active compounds or phytochemicals in plants, especially fruits, have been associated with numerous health benefits [3] and are used as ingredients in many nutraceutical and pharmaceutical products today. Radhika et al. [2] listed some sources of active ingredients from plants being used in manufacture of nutraceuticals. There are at least fourteen classes of secondary metabolites (chemical compounds) from fruits and vegetables that exert biological activities and can potentially be used to promote human health. These include alkaloids, amines, cyanogenic glycosides, diterpenes, flavonoids, glucosinolates, monoterpenes, non-protein amino acids, phenylpropanes, polyacetylenes, polyketides, sesquiterpenes, tetraterpenes, triterpenes, saponins and steroids [4]. Research by Mukherjee et al. [5] highlighted some chemical compounds from from various parts of plants that exhibit potential antioxidant activities, including madecossoside, asiaticoside, catechin, epicatechin, 4-hydroxycinnamic acid, esculetin, curcumin, xanthorrhizol, anthocyanins, diosgenin, gallic acid, ginsenoside, $\beta$-carotene, ginsenoside and cyanidin-3-glucoside. However, plant extracts can be toxic and contain excessive lethal constituents such as aristolochic acids, pyrrolizidone alkaloids, benzophenanthrine alkaloids, viscotoxins, saponins, diterpenes, cyanogenetic glycosides and furanocoumarins [6]. These compounds can affect human health since nutraceutical products, unlike pharmaceutical products, are not as well regulated and are commonly consumed without supervision or medical guidance. On the other hand, phenolic compounds from a variety of fruits such as catechin, anthocyanins, quercetin, kaempherol, resvasterol, curcuminoids, genistein, apigenin, carotenoids, carnosic acid, caffeic acid and ferulic acid are known to possess antioxidant activities and a sun-protective effect against UV light-induced damage [7]. Catechin, for example, has potent biological activity in cancer prevention, and has antioxidant, cardiovascular protection and hepatoprotective properties [8].

Pods are usually discarded when consuming fruits. The pod is the outer layer of some fruits which is hard in texture and is sometimes too bitter or astringent to be eaten raw, as in the case of mangosteen and cocoa. Pods are also called pericarps or rinds that surround the seeds [9]. The pericarp consists of three main parts, namely the epicarp or exocarp, mesocarp and endocarp. The outermost part, the epicarp, is usually called the skin or peel of the fruits. The middle layer, mesocarp, can be edible in some fruits such as mango, or fibrous like in palm oil fruit. Finally, the endocarp encloses the seeds. It occurs in various forms, such as the hard shell of coconuts or the soft shell of cocoa [10]. In between the mesocarp and endocarp, there is also a part called the aril or placenta of the seed that can be consumed. This part is usually white in color and juicy as an attractant to animals in order for the plant to grow diversely [11].

Representing the outer part of the fruits, the pericarp comes in various colors and changes during ripening depending on the types of fruits. For example, cocoa pods when ripened turn yellow from 
either red maroon or green. As another example, ripe mangosteens turn dark purple from green. Some pods turn brown, black or dark brown. The color results from pigments and phytochemicals such as chlorophyll, carotenoids and phenolics [12]. Red fruits are associated with compounds like lycopene, ellagic acid, quercetin and hesperidin, while orange and yellow fruits are usually linked to $\beta$-carotene, zeaxanthin, flavonoids and vitamin $C$ [13]. Chlorophyll, lutein, zeaxanthin and $\beta$-carotene are related to green fruits [14]. Blue and purple colors of fruits are often applied to resveratrol, quercetin and ellagic acid [15]. Finally, white colour is associated with the presence of $\beta$-glucans and lignans [16]. Although tristimulus colorimeters can be used to measure the visual appearance of fruit pericarp [17], identifying the profiles of the pericarp content should be carried out by analytical instrumentation to confirm the exact active compounds that exist in it.

This review focuses on bioactive compounds or phytochemicals of fruit pods with beneficial health effects that have potential pharmaceutical and nutraceutical applications. This review provides researchers with useful knowledge and guidance in future experimental work on developing pharmaceutical and nutraceutical products from this part of fruits. The available literature was searched using Google Scholar, Science Direct and Springer Link for scientific publications published during the period 1992-May 2012 describing beneficial aspects of bioactive components from fruit pods. In fact, certain fruits like mangosteen, carob, Acacia nilotica and Moringa oleifera and their pods have been extensively studied. Keywords used for the search were bioactive compounds, fruit pods, nutraceutical, pharmaceutical and plant names. This review focuses on the beneficial effects of bioactive compounds from fruit pods through the review by available in-vitro, pre-clinical and/or human trial studies in the related literature.

\section{Garcinia mangostana}

G. mangostana is also known as mangosteen or manggis in Malaysia. Although this plant grows well in tropical areas of the World, including Malaysia, Thailand and Indonesia, the nutraceutical products of mangosteen have been patented by Garrity et al. [18] from the USA and successfully marketed worldwide. Two major groups of phytochemicals in the mangosteen pericarp are the xanthones and phenolics. The antioxidant properties of G.mangostana is related to the presence of high levels of phenolic compounds (tannins) in its methanol, and ethanol extracts [19]. The phenolic compounds in mangosteen, including afzelechin, epiafzelechin, catechin, epicatechin, gallocatechin and epigallocatechin, can proiduce oxygen radical scavenging capacities as high as $1.7 \times 10^{4} \mu \mathrm{mol}$ $\mathrm{TE} / \mathrm{g}$, which is greater than those of grape seed and pine bark [20]. The quantity of phenolic compounds and antioxidant activity in the mangosteen pericarp is ten times and 20 times greater, respectively, than in the white edible parts.

Identification of mangosteen pericarp components, carried out by Asai et al. and Jung et al. [21,22], revealed that the xanthone group includes $\alpha-, \beta$-, and $\gamma$-mangostins, gartanin, garcinone $\mathrm{E}$, garcinone D, tovophyllin, mangostinone, smeathxanthone, 1-isomangostin, eudraxanthone G, 1,5-dihydroxy-2-(3-methylbut-2-enyl)-3-methoxy- and 1,7-dihydroxy-2-(3-methylbut-2-enyl)-3methoxyxanthone. A high content of xanthones has been detected in the pericarp when compared with the white aril part of the fruits, with seven main components identified as the fingerprint of mangosteen extract (1,7-dihydroxy-3-methoxy-2-(3-methylbut-2-enyl)xanthone, $\gamma$-mangostin, 
8-deosygartanin, 1,3,7-trihydroxy-2,8-di(3-methylbut-2-enyl)xanthone, gartanin, $\alpha$-mangostin and garcinone E) [23]. The xanthones also exhibited strong antioxidant properties. The extract of mangosteen rind in dichloromethane revealed that the xanthone compounds are also present in high concentrations; especially $\alpha$-mangostin that exhibited the strongest activity against bacteria that induce acne, including Propionibacterium acnes, Staphylococcus epidermidis [24] and oral candidiasis, Candida albicans [25]. The compound $\alpha$-mangostin isolated from mangosteen extract $(1.0 \mu \mathrm{g} / \mathrm{mL})$ also showed the most effective inhibitory effect against a preneoplastic lesion (leading to breast cancer) in a mouse mammary organ study [22].

Medicinal properties of G. mangostana have been summarized by Chaverri et al. [26] and show that the extract of this pericarp has antioxidant, antitumor, anti-inflammatory, antiallergy and antimalarial, besides anti-bacterial/viral properties. In addition, studies on the effect of mangosteen extract on obesity genes have also shown positive results [27-29]. The extract also reduced cholesterol level in rats [30]. The crude methanolic extract of mangosteen strongly inhibited human breast cancer cell profileration at $\mathrm{ED}_{50}$ of $9.25 \mu \mathrm{g} / \mathrm{mL}$ [31] and colon cancer cells [32]. In another study, crude methanolic extract of mangosteen also inhibited quinone reductase activity [33]. Nakatani et al. [34] studied the anti-allergy and anti-inflammatory effects of mangosteen pericarp extract in comparison with that of a traditional plant extract of Rubus suavissimus in Japan using in vitro studies. Mangosteen ethanol extract (40\%) inhibited histamine release and prostaglandin synthesis with greater effect. The extract also inhibited the synthesis of cyclooxygenase [35], a rate-limiting enzyme, functionally important in fluid and electrolyte homeostasis, gastric acid secretion and platelet aggregation. Ethanolic (50\%) extract of G.mangostana has been shown to exhibit neuroprotective activity in vitro [36]. Human subjects who received mangosteen dietary supplements for one month also showed significantly enhanced immune responses [37]. On the other hand, polysaccharide from mangosteen pericarp extracted using hot water and precipitated with ethanol stimulated phagocytic cells and demolished intracellular bacteria, namely Salmonella enteritidis. The extract contained D-gallacturonic acid, L-rhamnose and D-galactose [38]. A different species of mangosteen, Garcinia cochinchinensis, also exhibited strong anticancer activity following the presence of the compound guttiferone. The extract of G.cochinchinensis pericarp was higher in xanthone as well as trimethyl citrate [39].

Most of pharmaceutical and nutraceutical properties of G. mangostana pod extract in the scientific papers were studied using in-vitro methods where the effects varied between cells and species depending on host metabolism and bioavailability of the extracted compounds. For example, the effective concentration of extracts to cancer cells of human was ten times higher than needed for mouse to inhibit proliferation of cells in-vitro. Therefore, human clinical trials are needed due to the different in-vitro potency. Meanwhile, the extraction method such as type and percentage of solvent used can affect the beneficial response such as a hot water prepared extract is lacking in glucose, as previously shown [38], thus requiring detailed identification of the compounds present the extract.

\section{Ceratonia siliqua}

C. siliqua is a plant of the Mediteranean regions. Also known as carob, the crude extract of the plant pod exhibited antioxidant properties higher than certain known polyphenols such as catechin, quercetin and gallic acid alone [40,41], due to the presence of carotenoids such as lutein, lycopene, $\alpha$-carotene 
and $\beta$-carotene. Compound identification using High Performance Liquid Chromatography (HPLC) showed that carob pods contain flavonoids of quercetin glycosides, catechin and epicatechin gallate, polyphenols of gallic acid and ellagic acid, and anthocyanins such as proanthocyanidins and ellagitannins [42], as well as epigallocatechin gallate [43].

Avallone et al. [44] revealed that extract of carob pod can be used as a natural product with anxiolytic-sedative effects and act as a chemopreventive agent. The presence of gallic acid, epigallocatechin-3-gallate and epicatechin-3-gallate in carob pod can exert antiproliferative effects in-vitro [45]. Proliferative effects are related to cancerous cells that grow and increase rapidly. The patented aqueous extract of $C$. siliqua pod revealed the antioxidant activity of the extract along with potential antitumor activity [43]. The extract has equivalent antioxidant level to tea, but without the stimulant effects of caffeine and theophyline. The extract was prepared using hot distilled water for 15 minutes, then filtered and evaporated to dryness. The polyphenols content of the extract was $1.36 \mathrm{mg} / \mathrm{g}$ of pod powder. The pod extract at a concentration of $80 \mu \mathrm{g} / \mathrm{mL}$ was shown to effectively inhibit proliferation in liver tumor cells after 48 hours of treatment in-vitro. The extract of carob pod also has an antidepressant effects as exhibited in a study by Agrawal et al. on mice using tail suspension and forced swim tests [46]. The anti-diarrhea effect of carob pod dietary fiber, as patented by Mark et al. was observed in tube-fed patients [47]. Dietary fiber of carob pod also proved to reduce total cholesterol and LDL-c levels significantly after six weeks of consumption before breakfast in 49 volunteers with mild to moderate cholesterol levels [48].

Generally, pod extracts of $C$. siliqua were shown to posesses health benefits for humans. However, the in vitro antiproliferative and other beneficial effects need to be confirmed and extensively studied to evaluate its effectiveness in-vivo. The high antioxidant level of $C$. siliqua pod extract suggesting its potential development as a nutraceutical or pharmaceutical product.

\section{Moringa oleifera}

M. oleifera is a semi-arid plant [49], which can be found in tropical and subtropical climates. The plant, which is also known as the horseradish tree, can be found in India, Thailand, Africa and Indonesia. Research has shown that biologically active components present in this plant contributing to its health benefits are simple sugars and compounds called glucosinolates and isothiocyanates, including 4-(4'-O-acetyl- $\alpha$-L-rhamnopyranosyloxy)benzyl isothiocyanate, niazimicin, pterygospermin, benzyl isothiocyanate and 4-( $\alpha$-L-rhamnopyranosyloxy)benzyl glucosinolate, as well as carotenoids [50]. Two other compounds, niaziridin and niazirin, were also detected in M. oleifera pod by reverse phase HPLC [51].

Reportedly, M. oleifera pod has antioxidant activity [52], which is due to the presence of carotenoid compounds. The pod contains high amounts of bio-enhancers in comparison with the bark. It can be used to reduce cholesterol and glucose in blood with the safe intake level determined at $\leq 1,000 \mathrm{mg} / \mathrm{kg}$ body weight [53]. The ethanolic pod extract also showed hypotensive activity at a $30 \mathrm{mg} / \mathrm{kg}$ dose [54]. According to Jakansul et al. [55], the hypertensive effect was due to the thiocarbamate glycoside extracted from the pod. Intake of pod powder of $M$. oleifera was also shown to cause significant reduction in total cholesterol and total lipid levels of high lipid and high cholesterol diet-induced rabbits [56]. 
Antiurolithiatic activity was also exhibited by the extract of Moringa oleifera pods as studied by Vijayalakshmi et al. [57]. The extraction was carried out using boiling water for six hours and evaporation to dryness. Urolithiasis-induced albino rats were treated with the extract for one month. In comparison with the control group, rats fed with the plant extract at $400 \mathrm{mg} / \mathrm{kg}$ body weight showed significant reduction in stone weight.

A significant anti-inflammatory action was revealed by Rakesh et al. [58] in a study of the effects of $M$. oleifera ethanolic extract on carrageenan-induced paw edema in albino mice. The study was carried out to compare the relative effect of pod extract to diclofenac sodium, where the required dose of pod extract was $1,000 \mathrm{mg} / \mathrm{kg}$. Methanolic extract of fresh M. oleifera fruits also exhibited an anti-inflammatory effect in-vitro as observed by Cheenpracha et al. and Muangnoi et al. [59,60].

Aqueous ethanolic extract of M. oleifera also has a hepatoprotective effect, which was exhibited in albino mice with induced hepatocarcinogeniticity [61]. The effectiveness of pod extract was also apparent in repairing liver damaged by carbon tetrachloride in albino mice at $750 \mathrm{mg} / \mathrm{kg}$ [62]. Moreover, a niaziridin-rich extract fraction of $M$. oleifera pods enhanced the bioactivity of several antibiotics (rifampicin, tetra cycline and ampicillin) against bacteria and facilitated drug absorption through the gastrointestinal membrane [63].

The above studies indicate the beneficial effects on health by M. oleifera pod extracts. Although most of the effects were observed in animal models, these benefits may be extended to humans in the form of dietary supplements in the future.

\section{Acacia nilotica}

Planted in the Arabian Peninsula, Pakistan, India and Burma, Acacia nilotica is also known as the gum arabic tree. The pod of this Egyptian medicinal plant contains gallocatechin 5-O-gallate, methyl gallate, gallic acid, catechin, catechin 5-O-gallate, 1-O-galloyl- $\beta$-D-glucose, 1-6-di- $O$-galloyl- $\beta$-Dglucose and digallic acid. Its green pod is high in gallic acid, elagic acid, ferulic and epicatechin [8].

Formerly, the plant extract was used as a tanning [64] and dying agent. The plant itself was very useul since it provided water and insect-resistant wood, fodder for livestock and folk medicines. The pods were used to treat fever, diarrhea, diabetes, sore gums and skin diseases. Studies indicate that the pod extract of $A$. nilotica exhibits antioxidant, chemopreventive, antidiabetic, hypolipidemic and antiplasmodial activities $[64,65]$. The extraction was carried out by soaking of $44.2 \mathrm{~g}$ A. nilotica pod overnight in $500 \mathrm{~mL}$ of methanol three times. After filtration and solvent removal, the crude extract was fractionated using the solvents $n$-hexane, methanol, ethyl acetate, buthanol and water [8]. The aqueous methanolic extract of Acacia nilotica pod also caused significant reduction of blood glucose, plasma total cholestrol, triglycerides and low-density lipid (LDL) levels in alloxan-induced diabetic rabbits at $400 \mathrm{mg} / \mathrm{kg}$ body weight in a one-month treatment [66]. The ethyl acetate fraction of the pod exhibited antidiarrheal activity in albino rats at $400 \mathrm{mg} / \mathrm{kg}$ body weight [67]. Freeze dried extract of A. nilotica pods showed bactericidal activity against an extended spectrum of $\beta$-lactamase (ESBL) and methicillin-resistant Staphylococcus aureus (MRSA), as studied previously [68]. Another species of acacia, Acacia auiculiformis, has abundant amounts of acaciaside (tripernoid) in its pericarp that exhibits antifilarial activity [69]. 
Nutraceutical products could possibly be produced by using A. nilotica pod extract as a source of dietary fibre. Even though effective antidiarrheal effects have been determined in animals models, its efficacy in humans also need to be addressed in future studies.

\section{Sapindus rarak}

Sapindus rarak is the soapberry plant, known in Indonesia as lerai or kelerak. Traditionally, the pericarp was used for skin disorders. Four triterpene saponins have been identified in S. rarak pericarp, including rarasaponins (I, II, and III), raraoside, along with 13 other known saponins and four known acyclic sesquiterpene glycosides. A study revealed that the methanolic extract of Sapindus rarak pericarp contains saponins that inhibited pancreatic lipase and reduced lipid digestion in-vitro with an $\mathrm{IC}_{50}$ of $614 \mu \mathrm{g} / \mathrm{mL}$ [70]. The antiobesity effects of this plant were more strongly exhibited by raraoside and rarasaponin in comparison with the saponin compounds. A study on the effects of the methanolic extract of Sapindus rarak on plasma trigylceride elevation was conducted in mice treated with olive oil [71]. The results indicated that elevation of triglycerides was inhibited at a dose of $200 \mathrm{mg} / \mathrm{kg}$ by the saponin constituents, including hederagenin. The extract also exhibited inhibitory effects on tumor necrosis at a concentration of $30-100 \mu \mathrm{M}$, as reported by Morikawa et al. [72].

S. rarak has potential to be used in the formulation of nutraceutical products with weight loss effects due to the presence of bioactive compounds that inhibit lipid digestion. However, the effective dose of extract must be determined prior to its incorporation into products due to its high content of saponins.

\section{Prosopis cineraria}

P. cineraria or Khejri is also known as the king of the desert. The plant grows well in Western and Southern Asia, including Afghanistan, Iran, India, Oman, Pakistan and Saudi Arabia. When the boiling water extract of its pods is fractionated using methanol and trichloromethane, it results in the isolation of compounds such as 3-benzyl-2-hydroxy-urs-12-en-28-oic acid and maslinic acid-3-glucoside (triterpernoids); linoleic acid (fatty acid); prosophylline (piperidine alkaloid); 5,5'-oxybis-1,2benzanediol; 3,4,5-trihydroxycinnamic acid 2-hydroxyethyl ester; and 5,3',4'-trihydroxyflavanone 7-glycoside (polyphenols). In vitro bioassays carried out by Liu et al. [73] using these compounds and crude extract have shown positive results supporting its health benefits in preventing a wide range of illnesses including protein and mineral deficiencies. High antioxidant activity has also been exhibited by the methanolic extract of its pods, which also have indicated antimicrobial activity against Candida albicans [74]. There is also empirical proof that P. cineraria can exhibit estrogenic activity in vitro [75].

Although most of the biological activities showed in studies were proven in animals, there are potential benefits of $P$. cineraria pod extract as an antioxidant. However, the toxicity effects of the extracts need to be determined as the extract contains piperidine alkaloids which might exert certain adverse effects when consumed, as mentioned by Bahorun et al. [6].

\section{Other Ethnobotanicals}

There are several other plant pods which are used in traditional medicines for health and medicinal (ethnobotanical) purposes. However, most of the related publications focus on the biological activity 
of the pod crude extracts without any detailed identification of the extract itself. Ethanol extract of unripe Bauhinia purpurea exhibited an anti-obesity effect in cholesterol and high fat diet (CHFD)-induced hyperlipidemic rats [76]. As it was observed in this study, feeding the rats with CHFD together with unripe pods at $300 \mathrm{mg} / \mathrm{kg}$ /day lowered the body weight increase by $7.4 \%$ in comparison with hyperlipidemic rats $(13.11 \%)$ in the control group. The crude extract of unripe B. purpurea pods was reported to contain carbohydrates, proteins, alkaloids, flavonoids, triterpenes, glycosides and steroids.

Parkia speciosa or stinky bean (petai in Malaysia) has also exhibited antioxidant properties due to its high total phenolic and high flavonoid contents [77]. Oral administration of chloroform extracts of $P$. speciosa pod to diabetic-induced rats resulted in a significant reduction of blood glucose levels which suggests the potential use of the extract as an oral hypoglyceamic agent [78]. The methanolic extract of the Parkia speciosa pod also exhibited a significant antiangiogenic effect [79]. The ethanol extract of Cassia occidentalis pod showed antifungal activity towards Aspergillus clavatus at $100 \mu \mathrm{g} / \mathrm{mL}$, which was equal to the concentration required using commercial drugs such as nystatin and griseofulvin. Although a higher minimum inhibitory concentration (MIC) value was needed to inhibit Candida albicans and Aspergillus niger (125 and $500 \mu \mathrm{g} / \mathrm{mL}$, respectively), the inhibitory effect of the pod extract was comparable to the said drugs [80].

The extract of Albizia julibrissin Durazz pod exhibits antioxidant activity and a strong inhibition against E. coli, S. aureus, B. megaterium, B. subtilis and S. typhi [81]. However, a report [82] indicated that methanolic extract of Albizza lebbeck pod decreased the fertility of male albino rats significantly, without stating whether the effect was reversible or not. Nearly, $45 \%$ of the pod compounds are aromatic. $n$-Hexane extract of Samanea saman pods contains phytochemicals such as cyanidin, catechin, epicachin, anthocyanin monoglycones, delphinidin and malidin. Potent antibacterial properties, including against Candida albicans, have been exhibited by the ethyl acetate fraction of Samanea saman at 10,000 ppm [83]. Moderate antibacterial activity against Bacillus subtilis and Pseudominas aeruginosa was exhibited by the water extract of Cassia fistula pod [84].

Fruit pericarp of Emblica officinalis (used in Ayurveda treatment) contains hydrolysable tannins such as emblicanin, punigluconin and pedunculagin with significant antioxidant properties [85]. Extracts of Catalpa bignonoides pods exhibit anti-inflammatory and antinociceptive effects due to the presence of saponin, sterol or phenol compounds in the pods [86]. These properties are also exhibited by Tecoma sambucifolia [87]. Anti-inflammatory activity has also been observed in polysacharide extract of Caesalpinia ferrea pods [88]. Beneficial effects of Astragalus hamosus pod extract on edema-induced rats has also been reported by Hakim et al. [89], who observed a significant reduction in the size of rats' hind paws 3 hours after injection. The aqueous and alcoholic extracts of the pod exhibit a similar significant effect. Methanol extract of Caesalpinia pulcherrima pods showed significant anti-inflammatory effects when edema-induced rats were fed with pod extract at $400 \mathrm{mg} / \mathrm{kg}$ body weight in comparison with the control rats [90]. Pod extract of Cassia italica also exhibited anti-inflammatory effects on carragenan-induced paw swelling. The aqueous ethanol (80\%) extract also exhibited anti-pyretic activity [91].

The summary of biological activity of compounds of fruit pods associated with health benefits is presented in Tables 1 and 2. Some potential products that can be suggested from the pod extracts of ethnobotanical plants are those such as anti-inflammatory drugs, antibacterial creams and even dietary 
supplements which may assist in reducing blood pressure and blood glucose concentration. Although, human clinical trials are a must, positive findings from animal and in vitro studies indicate that the benefits of pod extracts should be explored further.

Table 1. Bioactive compounds and health benefits of fruit pods.

\begin{tabular}{|c|c|c|c|}
\hline Pod extract & Bioactive compounds & Health benefits & References \\
\hline Acacia nilotica & $\begin{array}{l}\text { Gallocatechin-gallate, methyl gallate, } \\
\text { gallic acid, catechin, catechin gallate, } \\
\text { galloyl-glucose, digallic acid, ellagic acid, } \\
\text { ferulic acid, epicatechin }\end{array}$ & $\begin{array}{l}\text { Reduced fever, antidiarrhea, } \\
\text { antioxidant, chemopreventive, } \\
\text { antidiabetic, reduced cholesterol, } \\
\text { hepatoprotective, antibacterial, } \\
\text { antifilarial }\end{array}$ & {$[61-66]$} \\
\hline $\begin{array}{l}\text { Bauhinia } \\
\text { purpurea }\end{array}$ & $\begin{array}{l}\text { Alkaloids, flavonoids, triterpenes, } \\
\text { glycosides, steroids }\end{array}$ & $\begin{array}{l}\text { Anti-angiogenic or cancer } \\
\text { treatment, hypolipidemic }\end{array}$ & {$[73]$} \\
\hline $\begin{array}{l}\text { Catalpa } \\
\text { bignonoides }\end{array}$ & Saponins, sterols, phenols & $\begin{array}{l}\text { Anti-inflammatory, } \\
\text { antinociceptive }\end{array}$ & {$[83]$} \\
\hline $\begin{array}{l}\text { Ceratonia } \\
\text { siliqua }\end{array}$ & $\begin{array}{l}\text { Polyphenols: catechin, quercetin, gallic } \\
\text { acid, quercetin glycosides, epicatechin } \\
\text { gallate, ellagic acid, proanthocyanidins, } \\
\text { ellagitannins; Carotenoids: lutein, lycopene, } \\
\text { carotene; Dietary fiber }\end{array}$ & $\begin{array}{l}\text { Antioxidant, anxiolytic-sedative } \\
\text { effect, chemopreventive, } \\
\text { antitumor, antidepressant, } \\
\text { antidiarrhea, reduced cholesterol }\end{array}$ & {$[41-46]$} \\
\hline $\begin{array}{l}\text { Emblica } \\
\text { officinalis }\end{array}$ & $\begin{array}{l}\text { Hydrolysable tannin: emblicanin, } \\
\text { punigluconin, pedunculagin }\end{array}$ & Antioxidant & {$[82]$} \\
\hline $\begin{array}{c}\text { Garcinia } \\
\text { mangostana }\end{array}$ & $\begin{array}{l}\text { Xanthone: mangostin, gartanin, garcinone, } \\
\text { tovophyllin, mangostinone, smeathxanthine, } \\
\text { isomangostin, eudraxanthone, } \\
\text { methixyxanthone; } \\
\text { Polyphenols: afzelechin, epiafzelechin, } \\
\text { catechin, epicatechin, gallocatechin, } \\
\text { epigallocatechin; } \\
\text { Glucose; D-gallacturonic acid, } \\
\text { L-rhamnose, D-galactose }\end{array}$ & $\begin{array}{l}\text { Chemopreventive, antibacterial, } \\
\text { antifungal, antioxidant, } \\
\text { antimalarial, antiallergy, } \\
\text { anti-inflammation, anti-obese, } \\
\text { reduced cholesterol, enhance } \\
\text { immune system }\end{array}$ & {$[20-35]$} \\
\hline $\begin{array}{l}\text { Moringa } \\
\text { oleifera }\end{array}$ & $\begin{array}{l}\text { Niaziridin, niazirin, niazimicin, } \\
\text { pterygospermin, benzyl isothiocyanate, } \\
\text { glucosinolate, carotenoids }\end{array}$ & $\begin{array}{l}\text { Antioxidant, reduced cholesterol, } \\
\text { antidiabetic, antiurolithic, } \\
\text { hypotensive, anti-inflammatory, } \\
\text { hepatoprotective, antibacterial }\end{array}$ & {$[47-60]$} \\
\hline $\begin{array}{c}\text { Parkia } \\
\text { speciosa }\end{array}$ & Phenolic, flavonoids & $\begin{array}{c}\text { Antioxidant, antidiabetic, } \\
\text { antiangiogenic }\end{array}$ & [74-76] \\
\hline $\begin{array}{l}\text { Prosopis } \\
\text { cineraria }\end{array}$ & $\begin{array}{l}\text { Tripenoids: maslinic acid glucoside; } \\
\text { linoleic acid, prosophylline, polyphenols }\end{array}$ & $\begin{array}{l}\text { Antioxidant, antibacterial, } \\
\text { antifungal, estrogenic }\end{array}$ & {$[70-72]$} \\
\hline $\begin{array}{l}\text { Samanea } \\
\text { saman }\end{array}$ & $\begin{array}{l}\text { polyphenols: cyanidin, catechin, } \\
\text { epicachin, anthocyanin monoglycones, } \\
\text { delphinidin, malidin }\end{array}$ & Antibacterial & {$[80]$} \\
\hline Sapindus rarak & $\begin{array}{l}\text { Raraoside, rarasaponin, saponins, acyclic } \\
\text { sesquiterpene glycosides, hederagenin }\end{array}$ & Anti-obesity, chemopreventive & [67-69] \\
\hline
\end{tabular}


Table 2. Biological activity of Ethnobotanical Fruit Pods.

\begin{tabular}{|c|c|c|c|c|c|c|c|c|}
\hline Plant pod & $\begin{array}{c}\text { Anti- } \\
\text { inflammatory }\end{array}$ & $\begin{array}{c}\text { Anti- } \\
\text { inociceptive }\end{array}$ & Antioxidant & Antibacterial & Antifungal & $\begin{array}{l}\text { Reduce } \\
\text { fertility }\end{array}$ & $\begin{array}{c}\text { Reduce } \\
\text { fever }\end{array}$ & References \\
\hline $\begin{array}{c}\text { Albizia } \\
\text { julibrissin }\end{array}$ & & & $\sqrt{ }$ & $\sqrt{ }$ & & & & [78] \\
\hline Albizia lebbeck & & & & & & $\sqrt{ }$ & & [79] \\
\hline $\begin{array}{c}\text { Astragalus } \\
\text { hamosus }\end{array}$ & $\sqrt{ }$ & & & & & & & [86] \\
\hline $\begin{array}{l}\text { Caesalpinia } \\
\text { ferrea }\end{array}$ & $\sqrt{ }$ & & & & & & & [85] \\
\hline $\begin{array}{l}\text { Caesalpinia } \\
\text { pulcherrima }\end{array}$ & $\sqrt{ }$ & & & & & & & [87] \\
\hline Cassia fistula & & & & $\sqrt{ }$ & $\sqrt{ }$ & & & [81] \\
\hline Cassia italica & $\sqrt{ }$ & & & & & & $\sqrt{ }$ & [88] \\
\hline $\begin{array}{c}\text { Cassia } \\
\text { occidentalis }\end{array}$ & & & & & $\sqrt{ }$ & & & [77] \\
\hline $\begin{array}{c}\text { Tecoma } \\
\text { sambucifolia }\end{array}$ & $\sqrt{ }$ & $\sqrt{ }$ & & & & & & [84] \\
\hline
\end{tabular}

\section{Conclusions}

This review has highlighted that most extracts from plant pods (including mangosteen and M. oleifera) contain compounds with antioxidant, anti-inflammatory, antibacterial, antifungal and other biological activities. The antioxidative properties are mostly related to their high content of polyphenolics such as catechin and gallic acid. In addition, the presence of carotenoids in some pod extracts, such as in carob, can increase the antioxidant capacity, which may suggest a synergystic effect between polyphenols and carotenoid compounds in the pod extract, or with xanthones as in G. mangostana pod extract. Potent antibacterial activity against several microbes including E. coli and $S$. aureus, as well as antifungal activity towards $C$. albicans, were exhibited by the pod extracts. Anti-obesity effects have also been attributed to the extracts from fruit pods of Sapindus rarak, Garcinia mangostana, Moringa oleifera and Acacia nilotica. In addition, certain pod extracts can also offer anti-diarrheal effects due to their high dietary fibre content. With these known biological activities, therefore, plant pod extracts can be promoted for usage in pharmaceutical and nutraceutical products in the near future.

\section{Acknowledgments}

The authors would like to extend their thanks to Universiti Putra Malaysia and Malaysian Cocoa Board for the use of library facilities. Special thanks to those who has involved in data collection and record.

\section{References}

1. De Felice, L.S. The nutraceutical revolution, its impact on food industry. Trends Food Sci. Technol. 1995, 6, 59-61. 
2. Radhika, P.R.; Singh, R.B.M.; Sivakumar, T. Nutraceuticals: an area of tremendous scope. IJRAP 2011, 2, 400-415.

3. Lachance, P.A.; Das, Y.T. Nutraceuticals. Compr. Med. Chem. II 2007, 1, 449-461.

4. Thompson, M.D.; Thompson, H.J. Botanical diversity in vegetable and fruit intake: Potential health benefits. In Bioactice Foods in Promoting Health Fruits and Vegetables; Academic Press: San Francisco, CA, USA, 2010; pp. 3-17.

5. Mukherjee, P.K.; Maity, N.; Nema, N.K.; Sarkar, B.K. Bioactive compounds from natural resources against skin aging. Phytomedicine 2011, 19, 64-73.

6. Bahorun, T.; Necgheen, V.S.; Aruoma, O.I. Botanical drugs, nutraceuticals and functional foods: The context of Africa. In Nutraceutical and Functional Food Regulations in the United States and around the World; Bagchi, D., Ed.; Academic Press: New York, NY, USA, 2008; pp. 341-348.

7. Zaid, M.A.; Afaq, F.; Syed, D.N.; Mukhtar, H. Botanical antioxidants for protection against damage from sunlight. In Nutritional Cosmetics: Beauty from Within, 1st ed.; Aaron, T., Blair, R.M., Eds.; William Andrew Inc.: Oxford, UK, 2009; pp. 159-183.

8. Brahma, N.S.; Singh, B.R.; Singh, R.L.; Prakash, D.; Sama, B.K.; Singh, H.B. Antioxidant and anti-quorum sensing activity of green pod of Acacia nilotica L. Food Chem. Toxicol. 2009, 47, 778-786.

9. Balfour, J.H. Handbook to Illustration of Botany; W \& A.K Johnston: London, UK, 1870.

10. Bewley, J.D.; Black, M.; Halmer, P. The Encyclopedia of Seeds: Science, Technology \& Uses; CAB International: Cambridge, MA, USA, 2006; pp. 55-57.

11. Hion, A.G.; Duplantier, J.M.; Quris, R.; Feel, F.; Sourd, C.; Decoux, J.P.; Dubost, G.; Emmons, L.; Erard, C.; Hecketsweiler, P.; et al. Fruit characters as a basis of fruit choice and sees dispersal in a topical forest vertebrate. Oecologia (Berlin) 1985, 65, 324-327.

12. Lancaster, J.E.; Lister, C.E.; Reay, P.F.; Triggs, C.M. Influence of pigment composition on skin color in a wide range of fruit and vegetable. J. Am. Soc. Hort. Sci. 1997, 122, 594-598.

13. Penelope, P.V.; Collins, J.K.; Pair, S.D.; Roberts, W. Lycopene content differs among red-fleshed watermelon cultivars. J. Sci. Food Agric. 2001, 81, 983-987.

14. McGhie, T.K.; Ainge, G.D. Color in fruit of the genes Actinidia: Carotenoid \& chlorophyll compositions. J. Agric. Food Chem. 2002, 50, 117-121.

15. Kiraly, V.Z.; Tyihak, E.; Albert, L.; Nameth, Z.I.; Ketary, G. Identification \& management of resveratrol \& formaldehyde in parts of white \& blue grape berries. Acta Biol. Hung. 1998, 49, 281-289.

16. Fastnaught, C.E.; Barglund, P.T.; Holm, E.T.; Fox, G.J. Genetic \& environmental variation in beta-glucan content and quality parameters of baby food. Cropscience 1995, 36, 941-946.

17. Wrolstad, R. Color and pigment analyses in fruit products. Oregon State University: Corvallis, OR, USA; 1993; pp. 1-17.

18. Garrity, A.; Morton, G.A.; Morton, J.C. Nutraceutical mangosteen composition. U.S. Patent 6,730,333, 2004.

19. Pothitirat, W.; Chomnawang, M.T.; Gritsanapan, W. Free radical scavenging and anti-acne activities of mangosteen fruit rind extracts prepared by different extraction methods. Pharm. Biol. 2010, 48, 182-186. 
20. Fu, C.; Loo, A.E.K.; Chia, F.P.P.C.; Huang, D. Oligomeric proanthocyanidins from mangosteen pericarps. J. Agric. Food Chem. 2007, 55, 7689-7694.

21. Asai, F.; Tosa, H.; Tanaka, T.; Iinuma, M. A xanthone from pericarps of Gracinia mangostana. Phytochemistry 1995, 39, 943-944.

22. Jung, H.A.; Su, B.N.; Keller, W.J.; Mehta, R.G.; Kinghorn, D. Antioxidant xanthones from the pericarp of Garcinia mangostana (Mangosteen). J. Agric. Food Chem. 2006, 54, 2077-2082.

23. Wittenauer, J.; Falk, S.; Weisz, U.S.; Carle, R. Characterisation and quantification of xanthones from the aril and pericarp of mangosteens (Garcinia mangostana L.) and a mangosteen containing functional beverage by HPLC-DAD-MS. Food Chem. 2012, in press.

24. Pothitirat, W.; Chomnawang, M.T.; Gritsanapan, W. Anti-acne-inducing bacterial acticity of mangosteen fruit rind extracts. Med. Princ. Pract. 2010, 19, 281-286.

25. Kaomongkolgit, R.; Jamdee, K.; Chaisonboon, N. Antifungal activity of alpha-mangostin against Candida albicans. J. Oral. Sci. 2009, 51, 401-406.

26. Chaverri, J.P.; Rodriguez, N.C.; Ibarra, M.O.; Rojas, M.P. Medicinal properties of mangosteen (Garcinia mangostana). Food Chem. Toxicol. 2008, 46, 3227-3239.

27. Foti, R.S.; Pearson, J.T.; Rock, D.A.; Wahlstrom, J.L.; Wienkers, L.C. In vitro inhibition of multiple cytochrome $\mathrm{P} 450$ isoforms by xanthone derivatives from mangosteen extract. Drug Metab. Dispos. 2009, 37, 1848-1855.

28. Bumrungpert, A.; Kalpravidh, R.W.; Chitchumroonchokchai, C.; Chuang, C.C.; West, T.; Kennedy, A.; McIntosh, M. Xanthones from mangosteen prevent Lipopolysaccharide-mediate inflammation and insulin resistance in primary cultures of human adipocytes. J. Nutr. 2009, 139, $1185-1191$.

29. Bumrungpert, A.; Kalpravidh, R.W.; Chitchumroonchokchai, C.; Chuang, C.C.; Overman, A.; Kennedy, A.; McIntosh, M. Xanthones from mangosteen inhibit inflammation in human macrophages and in human adipocytes exposed to macrophase-conditioned media. J. Nutr. 2010, $140,842-847$.

30. Leontowicz, H.; Leontiwicz, M.; Drzewiecki, J.; Haruenkit, R.; Poovarodom, S.; Park, Y.S.; Jung, S.T.; Kang, S.G.; Trakhtenberg, S.; Gorinstein, S. Bioactive properties of snake fruit (Salacca edulis Reinw) and mangosteen (Garcinia mangostana) and their influence on plasma lipid profile and antioxidant activity in rats fed cholestrol. Eur. Food Res. Technol. 2006, 233, 697-703.

31. Moongkarndi, P.; Kosem, N.; Kaslungka, S.; Luanratana, O.; Pongpan, N.; Neungton, N. Antiproliferation, antioxidation and induction of apoptosis by Garcinia mangostana (mangosteen) on SKBR3 human breast cancer cell line. J. Ethnopharmocol. 2004, 90, 161-166.

32. Matsumoto, K.; Akao, Y.; Ohguchi, K.; Ito, T.; Tanaka, T.; Iinuma, M.; Nozawa, Y. Xanthones induce cell-cycle arrest and apoptosis in human colon cancer DLD-1 cells. Bioorg. Med. Chem. 2005, 13, 6064-6069.

33. Chin, Y.W.; Jung, H.A.; Chai, H.; Keller, W.J.; Kinghorn, A.D. Xanthones with reductaseinducing activity from the fruits of Garcinia mangostana (mangosteen). Phytochemistry 2008, 69, 754-758.

34. Nakatani, K.; Atsumi, M.; Arakawa, T.; Oosawa, K.; Shimura, S.; Nakahata, N.; Ohizumi, Y. Inhibitions of histamine release and prostaglandin E2 synthesis by mangosteen, a Thai medicinal plant. Biol. Pharm. Bull. 2002, 25, 1137-1141. 
35. Nakatani, K.; Nakahata, N.; Arakawa, T.; Yasuda, H.; Ohizumi, Y. Inhibition of cyclooxygenase and prostaglandin E2 synthesis by $\gamma$-mangostin, a xanthone derivative in mangosteen, in C6 rat glioma cells. Biochem. Pharmacol. 2002, 63, 73-79.

36. Weecharangsan, W.; Opanasopit, P.; Sukma, M.; Ngawhirunpat, T.; Sotanaphun, U.; Siripong, P. Antioxidative and neuroprotective actvities of extracts from the fruit hull of mangosteen (Garcinia mangostana Linn.). Med. Princ. Pract. 2006, 16, 281-287.

37. Tang, Y.P.; Li, P.G.; Kondo, M.; Ji, H.P.; Kou, Y.; Ou, B. Effect of a mangosteen dietary supplement on human function: a randomized, double-blind, placebo-controlled trial. J. Med. Food 2009, 12, 755-763.

38. Chanarat, P.; Chanarat, N.; Fujihara, M.; Nagumo, T. Immunopharmacological activity of polysaccharide from the pericarb of mangosteen garcinia: Phagocytic intracellular killing activities. J. Med. Assoc. Thai. 1997, 1, 49-54.

39. Nguyen, H.D.; Trinh, B.T.D.; Nguyen, L.H.D. Guttiferones QS, cytotoxic polyisoprenylated benzophenones from the pericarp of Garcinia cochinchinensis. Phytochemistry 2011, 4, 129-133.

40. Kumazama, S.; Tanaguchi, M.; Suzuki, Y.; Shimura, M.; Kwon, M.S.; Nakayama, T. Antioxidant activity of polyphenols in carob pods. J. Agric. Food Chem. 2002, 50, 373-377.

41. Makris, D.P.; Kefalos, P. Carob pods (Ceratonia silique L.) as a source of polyphenolic antioxidants. Food Technol. Biotechnol. 2004, 42, 105-108.

42. Khatib, S.; Vaya, J. Fig, carob, pistachio, and health. In Bioactice Foods in Promoting Health Fruits and Vegetables; Academic Press: San Francisco, CA, USA, 2010; pp. 245-263.

43. Baraldi, M. Aqueous extract of Ceratonia siliqua leaves and pods containing polyphenols with antioxidant and antitumor activities. Eur. Patent EP1438058B1, 2004.

44. Avallone, R.; Cosenza, F.; Farina, F.; Baraldi, C.; Baraldi, M. Extraction and purification from Ceratonia siliqua of compounds acting on central and peripheral benzodiazepine receptors. Fitoterapia 2002, 73, 390-396.

45. Corsi, L.; Avallone, R.; Cosenza, F.; Farina, F.; Baraldi, C.; Baraldi, M. Antiproliferative effects of Ceratonia siliqua L. On mouse hepatocellular carcinoma cell line. Fitoterapia 2002, 73, 674-684.

46. Agrawal, A.; Mohan, M.; Kasture, S.; Foddis, C.; Frau, M.A.; Loi, M.C.; Maxia, A. Antidepressant activity of Ceratonia silique L. fruit extract, a source of polyphenols. Nat. Prod. Res. 2011, 25, 450-456.

47. Mark, D.A.; Stalker, L. Low caloric density enteral formulation designed to reduce diarrhea in tube-fed patients. U.S. Patent 5,229,136, 1992.

48. Graubaum, H.J.; Gruenwald, J.; Haber, B.H.; Lueder, W. New Cholestrol-Lowering Dietary Fiber from Ceratonia siliqua, Proceeding of Whole Grain and Human Health International Symposium, Finland, 13-15 June 2001; Whole Grain and Human Health International Symposium: Helsinki, Finland, 2001.

49. Navie, S.; Csurhes, S. Weed Risk Assessment Horseradish Tree Moringa oleifera; Queensland State Education: Avoca, QLD, Australia, 2011.

50. Fahey, J.W. Moringa oleifera: A review of the medical evidence for its nutritional, therapeutic, and prophylactic properties. Part1. Trees Life J. 2005, 1, 1-5. 
51. Shanker, K.; Gupta, M.M.; Srivastava, S.K.; Bawankule, D.U.; Pal, A.; Khanuja, S.P.S. Determination of bioactive nitrile glycoside in drumstick (Moringa oleifera) by reverse HPLC. Food Chem. 2007, 105, 376-382.

52. Kumar, S.; Kumar, D.; Singh, N.; Vasisht, B.D. In-vitro free radicals scavenging and antioxidant activity of Moringa oleifera pods. J. Herb. Med. Toxicol. 2007, 1, 117-122.

53. Asare, G.A.; Gyan, B.; Bugyei, K.; Adjei, S.; Mahama, R.; Addo, P.; Nyarko, L.O.; Wiredu, E.K.; Nyarko, A. Toxicity potentials of the nutraceutical Moringa oleifera at suprasupplementation levels. J. Ethnopharmocol. 2012, 139, 265-272.

54. Faizi, S.; Shiddiqui, B.S.; Saleem, R.; Aftab, K.; Shaheen, F.; Gilani, A.H. Hypotensive constituents from the pods of Moringa oleifera. Planta Med. 1998, 64, 225-228.

55. Jakansul, C.; Wun-Noi, A.; Croft, K.; Byrne, I. Pharmacological studies of thiocarbamate glycosides isolated from Moringa oleifera. J. Sci. Soc. Thail. 1997, 23, 335-346.

56. Mehta, L.K.; Balaraman, R.; Amin, A.H.; Bafna, P.A.; Gulati, O.D. Effects of fruits Moringa oleifera on the lipid profile and hypercholestrolaemic rabbits. J. Ethnopharmacol. 2003, 86, 191-195.

57. Vijayalakshmi; Satish, K.M.C.; Fahad, J.; Prabhath, K.G.; Udupa, A.L.; Ratnakar, U.P. Antiurolithiatic activity of aqueous extract of Moringa oleifera (Lam.) pod in rats. Pharmacologyonline 2010, 3, 716-721.

58. Rakesh, S.; Singh, V.J. Anti-inflammatory activity of Moringa oleifera leaf and pod extracts against carrageenan induced paw edema in albino mice. Pharmacologyonline 2011, 1, 140-144.

59. Cheenpracha, S.; Park, E.J.; Yoshida, W.Y.; Barit, C.; Wall, M.; Pezzuto, J.M.; Chang, L.C. Potential anti-inflammatory phenolic glycoseds from the medicinal plant Moringa oleifera fruits. Bioorg. Med. Chem. 2010, 18, 6598-6602.

60. Muangnoi, C.; Chingsuwanrote, P.; Praengamthanachoti, P.; Svasti, S.; Tuntipopipat, S. Moringa oleifera pod inhibites inflammatory mediator production by liposaccharide-stimulated RAW264.7 murine macrophage cell lines. Inflammation 2011, 1-11.

61. Paliwal, R.; Sharma, V.; Pracheta, S.S.H. Hepatoprotective and antioxidant potential of Moringa oleifera pods against DMBA-induced hepatocarcinogenesis in male mice. Int. J. Drug Dev. Res. 2011, 3, 128-138.

62. Rakesh, S.; Singh, V.J. In vivo antioxidant activity of Moringa oleifera leaf and pod extracts against carbon tetra chloride induced liver damage in albino mice. J. Chem. Pharm. Res. 2010, 2, $275-283$.

63. Khanuja, S.P.S.; Arya, J.S.; Tiruppadiripuliyar, R.S.K.; Saikia, D.; Kaur, H. Nitrile glycoside useful as a bioenhancer of drugs and nutrients process of its isolation from Moringa oleifera. J. Biochem. 2005, 6, 858-888.

64. Salem, M.M.; Davidorf, F.H.; Rahman, M.H.A. In vitro anti-uveal melanoma activity of phenolic compounds from the Egyptian medicinal plant Acacia nilotica. Fitoterapia 2010, 82, 1279-1284.

65. Gilani, A.H.; Shaheen, F.; Zaman, M.; Janbaz, K.H.; Shah, B.H.; Akhtar, M.S. Studies on antihypertensive and antispasmodic activities of methanol extract of Acacia nilotica pods. Phytother. Res. 1999, 13, 665-669. 
66. Ahmad, M.; Zaman, F.; Sharif, T.; Zabta, M.C. Antidiabetic and hypolipidemic effects of aqueous methanolic extract of Acacia nilotica in alloxan-induced diabetic rabbits. Scand. J. Lab. Anim. Sci. 2008, 35, 29-34.

67. Sanni, S.; Thilza, I.B.; Talle, M.; Mohammed, S.A.; Sanni, F.S.; Okpoli, L.A.; Jajere, M.S.; Disa, S.H. The effect of Acacia nilotica pod ethyl acetate fraction on induced diarrhea in albino rats. N. Y. Sci. J. 2010, 3, 16-20.

68. Riaz, S.; Faisal, M.; Hanain, S.; Khan, N.A. Antibacterial and cytotoxic activities of Acacia nilotica Lam (mimosaceae) methanol extracts against extended spectrum beta-lactamase producing Eschericia coli and Klebsiella species. Trop. J. Pharm. Res. 2011, 10, 785-791.

69. Mahato, S.B. Chemistry of some natural products of biological interest. In Studies in Natural Products Chemistry; University of Karachi: Karachi, Pakistan, 2000; pp. 487-529.

70. Morikawa, T.; Xie, Y.; Asao, Y.; Okamoto, M.; Yamashita, C.; Muraoka, O.; Matsuda, H.; Pongpiriyadacha, Y.; Yuan, D.; Yomikawa, M. Oleanane-type triterpene oligoglycosides with pancreatic lipase inhibitory activity from pericarps of Sapindus rarak. Phytochemistry 2009, 70, 1166-1172.

71. Asao, Y.; Morikawa, T.; Xie, Y.; Okamoto, M.; Hamao, M.; Matsuda, H.; Muraoka, O.; Yuan, D.; Yoshikawa, M. Structures of acetylated oleanane-type triterpene saponins, rarasaponins IV, V, and VI, and anti-hyperlipidemic constituents from teh pericarps of Sapindus rarak. Chem. Pharm. Bull. 2009, 57, 198-203.

72. Morikawa, T.; Xie, Y.; Ninomiya, K.; Okamoto, M.; Muraoka, O.; Yuan, D.; Yoshikawa, M.; Hayakawa, T. Inhibitory effects of acylated acyclic sesquiterpene oligoglycosides from the pericarps of Sapindus rarak on tumor necrosis factor- $\alpha$-induced cytotoxicity. Chem. Pharm. Bull. 2010, 58, 1276-1280.

73. Liu, Y.; Singh, D.; Nair, M.G. Pods of khejri (Prosopis cineraria) consumed as a vegetable showed functional food properties. J. Funct. Foods 2011, 4, 116-121.

74. Salar, R.K.; Dhall, A. Antimicrobial and free radical scavenging activity of extracts of some Indian medicinal plants. J. Med. Plants Res. 2010, 4, 2313-2320.

75. Marquez, S.R.; Aguirre, F.G.; Alcantara, M.; Diaz, E.G.; Gutierrez, M.M.; Silva, M.A.; Lopez, G.; Romero, C.; Chemineau, P.; Keller, M.; Delgadillo, J.A. Mesquite pod extract modifies the reproductive physiology and behavior of the female rat. Horm. Behav. 2012, 61, 549-558.

76. Lakshmi, B.V.S.; Neelima, N.; Kasthuri, N.; Umarani, V.; Sudhakar, M. Antihyperlipidemic activity of Bauhinia purpurea extract in hypercholesterolemic albino rats. Int. J. PharmTech Res. 2011, 3, 1265-1272.

77. Gan, C.Y.; Aishah, A.L. Antioxidant Parkia speciosa pod powder as potential functional flour in food application: Physiochemical properties characterization. Food Hydrocoll. 2011, 25, 1174-1180.

78. Fathaiya, J.; Suhaila, M.; Nordin, L.M. Hypoglycaemic effect of Stigmast-4-en-3-one, from Parkia speciosa empty pod. Food Chem. 1995, 54, 9-13.

79. Aisha, A.F.A.; Abu-Salah, K.M.; Alrokayan, S.A.; Zhari, I.; Majid, A.M.S.A. Evaluation of antiangiogenic and antioxidant properties of Parkia speciosa Hassk extracts. J. Pharm. Sci. 2012, $25,7-14$. 
80. Viput, S.D.; Anjana, K.V. Antifungal activity of crude extracts of Cassia occidentalis. Int. J. Res. Phytochem. Pharmacol. 2011, 1, 36-38.

81. Lv, J.S.; Zhang, L.N.; Song, Y.Z.; Wang, X.F.; Chu, X.Z. Biological activity exhibited by secondary metabolites of the Albizia julibrissin Durazz. pod. Int. Biodeterior. Biodegrad. 2011, 65, 258-264.

82. Gupta, R.S.; Kachhawa, J.B.S.; Chaudhary, R. Antifertility effects of methanolic pod extract of Albizzia lebbeck (L.) Benth in male rats. Asian J. Androl. 2004, 6, 155-159.

83. Ukoha, P.O.; Cemaluk, E.A.C.; Nnamdi, O.L.; Madus, E.P. Tannins and other phytochemical of the Samanea saman pods and their antimicrobial activities. Afr. J. Pure Appl. Chem. 2011, 5, 237-244.

84. Mane, V.D.; Rajput, R.; Malpani, M.O.; Bhokare, D.D. Phytochemical investigation and antibacterial activity of various extract of Cassia fistula. Int. J. Chem. Res. 2012, 3, 13-16.

85. Bhattacharya, A.; Kumar, M.; Ghosal, S.; Bhattacharya, S.K. Effect of bioactive tannoid principles of Emblica officinalis on iron-induced hepatic toxicity in rats. Phytomedicine 2000, 7 , $173-175$.

86. Mingarro, D.M.; Acero, N.; Llinares, F.; Pozuelo, J.M.; Mera, A.G.; Vicenten, J.A.; Morales, L.; Alguacil, L.F.; Perez, C. Biological activity of extracts from Catalpa bignonioides Walt. (Bignoniaceae). J. Ethnopharmacol. 2003, 87, 163-167.

87. Alguacil, L.F.; Mera, A.G.; Gomez, J.; Llinares, F.; Morales, L.; Mingarro, M.D.M.; Pozuelo, J.M.; Orellana. J.A.V. Tecoma sambucifolia: anti-inflammatory and antinociceptive activities, and in vitro toxicity of extracts of the 'huarumo' of Peruvian Incas. J. Ethnopharmocol. 2000, 70, 227-233.

88. Pereira, L.P.; Silva, R.O.; Bringel, P.H.S.F.; Silva, K.E.S.; Assreuy, A.M.S.; Pereira, M.G. Polysaccharide fractions of Caesalpinia ferrea pods: Potential anti-inflammatory usage. J. Ethnopharmacol. 2012, 139, 642-648.

89. Hakim, A.; Tajuddin; Ghufran, A.; Nasreen, J. Evaluation of anti-inflammatory activity of the pods of Iklil-ul-Malik (Astragalus hamosus Linn.). Ind. J. Nat. Prod. Resour. 2010, 1, 34-37.

90. Khumbare, M.; Sivakumar, T. Anti-inflammatory and antinociceptive activity of pods of Caesalpinia pulcherrima. J. Appl. Pharm. Sci. 2010, 1, 180-184.

91. Jain, S.C.; Jain, R.; Sharma, R.A.; Capasso, F. Pharmacological investigation of Cassia italica. J. Ethnopharmacol. 1997, 58, 135-142.

(C) 2012 by the authors; licensee MDPI, Basel, Switzerland. This article is an open access article distributed under the terms and conditions of the Creative Commons Attribution license (http://creativecommons.org/licenses/by/3.0/). 